\title{
PERAN GURU PENDIDIKAN AGAMA ISLAM DALAM MENDISIPLINKAN SHALAT BERJAMA'AH PESERTA DIDIK DI SMK MUHAMMADIYAH 3 GRESIK
}

\author{
Nurullia Anggraini \\ Noor Amiruddin \\ Universitas Muhammadiyah Gresik \\ Email: nurulia.anggraini@gmail.com
}

\begin{abstract}
Abstrak: Shalat adalah media komunikasi antara makhluk dan sang khalik. Shalat adalah pencegah dari perbuatan keji dan munkar. Kalau melihat realitas sekarang di kalangan remaja sudah banyak terjadi kelalaian dalam banyak hal. Oleh karena itu, perlu adanya kebiasaan shalat berjamaah di sekolah agar pembiasaan baik sejak dini tertanam dalam diri remaja. Penelitian ini difokuskan pada peran guru PAI dalam mendisiplinkan shalat berjamaah peserta didik di SMK Muhammadiyah 3 Gresik dengan rumusan masalah sebagai berikut: (1) peran guru PAI dalam mendisiplinkan shalat berjamaah peserta didik (2) faktor pendukung dan penghambat dalam mendisiplinkan shalat berjamaah peserta didik. Untuk mencapai tujuan tersebut menggunakan metode deskriptif kualitatif, adapun pengumpulan data yang digunakan adalah observasi, wawancara, dan dokumentasi. Peneliti menggunakan analisis deskriptif yang bertujuan untuk menjelaskan aspek yang relevan dengan fenomena yang diamati. Hasil penelitian menunjukkan bahwa: (1) Guru memberikan contoh (sebagai teladan yang baik), memberikan nasihat yang baik, memberikan hukuman, (2) kerja sama yang baik antara guru PAI dan guru yang lain, peran guru PAI yang berjalan dengan baik, lokasi, dan waktu. Dengan diadakan shalat berjamaah di sekolah maka akan menjadikan siswa terbiasa melakukan shalat berjamaah di mana pun dengan tepat waktu. Kegiatan ini sangat baik dilaksanakan karena sesuai dengan kurikulum tentang shalat yang selanjutnya dapat mengaplikasikan kegiatan di sekolah maupun di rumah. Kegiatan shalat berjamaah tersebut dengan maksud untuk mendisiplinkan shalat berjamaah peserta didik.
\end{abstract}

Kata Kunci: guru PAI, kedisiplinan, shalat jamaah 


\section{PENDAHULUAN}

$\mathrm{M}$

anusia merupakan makhluk yang paling sempurna di antara makhluk-makhluk cip-

taan Allah lainnya. Dalam kehidupannya manusia dihadapkan dengan berbagai macam tantangan baik bersifat spiritual maupun emosional. Namun hal itu semua dapat diatasi dengan baik jika pada diri manusia memiliki karakter unggul dan berkualitas. Peran karakter tidak dapat disisihkan dalam proses perkembangan, karakter inilah yang menempatkan baik tidaknya seseorang, posisi karakter bukan jadi pendamping kompetensi melainkan menjadi dasar, ruh atau jiwanya. Tanpa karakter peningkatan diri dari kompetensi akan menjadi liar, seperti halnya berjalan tanpa rambu. ${ }^{1}$

Sehingga dalam hal ini karakter disiplin dirasa sangat penting untuk menjadikan hidup lebih baik. Maka dalam lingkungan pendidikan setiap lembaga atau sekolah menginginkan agar setiap peserta didik memiliki karakter disiplin pada dirinya. Mengingatnya generasi muda saat ini yang memiliki disiplin rendah, tidak dapat mengatur kehidupannya dan mereka lalai dalam banyak hal. Seperti halnya peneliti jumpai pada waktu magang di SMK Muhammadiyah 3 Gresik beberapa dari

${ }^{1}$ Erie Sudewo, Character Building Menuju Indonesia Lebih Baik, (Jakarta: Republika, 2011), hal. 13. peserta didik tidak disiplin dalam melakukan shalat berjamaah khususnya. Contohnya, pada waktu Shalat dhuha dan dhuhur, beberapa dari peserta didik itu tidak segera bergegas untuk ke masjid, melainkan dudukduduk dan beli makanan di kantin. Selain itu, pada waktu Shalat dhuhur beberapa dari peserta didik ada yang tidur di kelas dan tidak melaksanakan Shalat berjamaah. Maka permasalahan tersebut perlu disadari bahwa disiplin sangat dibutuhkan, karena dengan adanya disiplin semua pekerjaan akan berjalan dengan baik.

Disiplin yang dimaksud adalah kepatuhan untuk menghormati dan melaksanakan sebuah sistem atau menaati dan ketentuan yang telah ditetapkan. Di antara peraturan tersebut ada yang sengaja dibuat untuk kepentingan seseorang atau sekelompok orang seperti disiplin beragama, disiplin waktu, disiplin bernegara, disiplin bermasyarakat, disiplin sekolah, disiplin kantor, disiplin rumah tangga, disiplin lalu lintas, dan sebagainya. ${ }^{2}$

Disiplin adalah kunci sukses dari setiap kegiatan. Kegiatan yang didasari dengan disiplin akan tumbuh sifat yang teguh dan tekun dalam segala urusan termasuk dalam belajar dan beribadah. Sebagai lembaga pendidikan Islam akan menjadikan penanaman akidah sebagai salah satu program

2 Muhammad Idris Jauhari, Disiplin dan Hidup Disiplin, (Sumenep: Mutiara Press Al Amien Prenduan, 2011), hal. 1. 
unggulan. Maka penerapan kegiatan Shalat berjamaah dilakukan di sekolah oleh seluruh warga sekolah. Untuk itu guru dan pengurus sekolah harus menanamkan sikap disiplin dalam pelaksanaan Shalat berjamaah sehingga peserta didik mampu melaksanakan Shalat berjamaah pada awal waktunya dan peserta didik dapat mengatur waktu dengan baik.

Dalam penanaman disiplin dalam Shalat berjamaah di sekolah tentu tidak lepas dari pantauan dan bimbingan dari para guru. Guru merupakan seseorang yang berperan penting dalam pelaksanaan pendidikan dan tingkah laku seorang guru akan dijadikan sebagai teladan bagi peserta didik. ${ }^{3}$ Namun pemberian teladan oleh guru tidak cukup jika setiap peserta didik tidak mengetahui fungsi dan manfaat disiplin dan beribadah. Oleh karena itu sebagai guru perlu memberikan pengetahuan tentang nilai-nilai agama secara mendalam agar tidak terjadi kebobrokan moral. Dan yang mempunyai andil besar dalam hal ini adalah guru PAI. Guru PAI memberikan pembinaan agama pada seluruh peserta didik, sehingga dapat meningkatkan spiritual peserta didik khususnya dalam melaksanakan ibadah shalat berjamaah.

SMK Muhammadiyah 3 Gresik yang merupakan sebuah amal usaha lembaga pendidikan menengah kejuruan di bawah naungan Muhammadiyah ini menanamkan pengetahuan akidah dan kedisiplinan dengan baik, berbeda dengan sekolah-sekolah SMK lainnya terutama yang ada di kota semen ini.

Dari uraian di atas, maka peneliti ingin mengambil judul yang ingin diteliti adalah "Peran Guru Pendidikan Agama Islam dalam Mendisiplinkan Shalat Berjamaah Peserta didik di SMK Muhammadiyah 3 Gresik".

\section{Rumusan Masalah}

Adapun beberapa masalah yang akan kami angkat, antara lain:

1. Bagaimana peran guru PAI dalam mendisiplinkan shalat berjamaah peserta didik di lingkungan SMK Muhammadiyah 3 Gresik?

2. Apa faktor pendukung dan penghambat dalam mendisiplinkan shalat berjamaah peserta didik di lingkungan SMk Muhammadiyah 3 Gresik?

\section{Batasan Masalah}

Penelitian ini agar lebih terarah, terfokus, dan menghindari pembahasan menjadi terlalu luas, maka penulis perlu membatasinya. Adapun batasan masalah

\footnotetext{
3 Rusman, Belajar dan Pembelajaran, (Jakarta:
} Kencana, 2017), hal. 146. 
dalam penelitian ini adalah pada shalat dhuha dan shalat dhuhur saja.

\section{Tujuan Penelitian}

Adapun tujuan penelitian ini, antara lain:

1. Untuk mendeskripsikan dan mengetahui peran guru PAI dalam mendisiplinkan shalat berjamaah peserta didik SMK Muhammadiyah 3 Gresik.

2. Untuk mengetahui faktor pendukung dan penghambat yang dihadapi guru PAI dalam mendisiplinkan shalat berjamaah peserta didik SMK Muhammadiyah 3 Gresik.

\section{TINJAUAN PUSTAKA}

\section{Penelitian Terdahulu}

Dalam penelitian ini, peneliti menemukan beberapa karya ilmiah atau penelitian sebelumnya yang mempunyai relevansi dan menjadi acuan penelitian ini, antara lain:

Pertama, skripsi yang ditulis oleh Nurul Huda mahasiswa Institut Agama Islam Negeri Salatiga yang berjudul "Peran Guru terhadap Keaktifan Siswa Melaksanakan Shalat". ${ }^{4}$ Dalam penelitian ini menjelaskan

4 Nurul Huda, Peran Guru Terhadap Keaktifan Siswa Melaksanakan Shalat, Skripsi-- Institut agama Islam Negeri Salatiga, 2015.

5 Ulfa Nurul Sangadah, Peran Guru Pendidikan Agama Islam dan Orang Tua dalam Membentuk bahwa peran guru di madrasah menjadi tanggung jawab guru dalam membawa keberhasilan siswa. Peran guru di MAN Tegalrejo dengan terjun langsung bersamasama melaksanakan shalat sunnah Dhuha dan shalat Dzuhur disekolah. Peran guru juga dalam bentuk membimbing, memotivasi, memberi contoh, mengarahkan siswa. Peran guru dan dukungan sekolah dalam bentuk tata tertib lembaga memperkuat keaktifan siswa melaksanakan ibadah shalat.

Kedua, skripsi yang ditulis oleh Ulfa Nurul Sangadah mahasiswi Institut Agama Islam Negeri Purwokerto yang berjudul "Peran Guru Pendidikan Agama Islam dan Orang Tua dalam Membentuk Kedisiplinan Ibadah Siswa Kelas XI IPA di SMA Negeri 1 Rembang Kabupaten Purbalingga".5 Dalam penelitian ini menjelaskan bahwa peran guru PAI dan orang tua sangat berperan penting. Peran guru PAI dalam membentuk kedisiplinan ibadah siswa di antaranya guru berperan sebagai inspirator, informator, pembimbing dan motivator.

Ketiga, skripsi yang ditulis oleh Himawan Puput Raharjo mahasiswa Institut Agama Islam Negeri Surakarta yang berjudul "Strategi Guru Pendidikan Agama Islam dalam Meningkatkan Kedisiplinan Siswa Kelas XI IPS 1 (Studi Kasus di SMA

Kedisiplinan Ibadah Siswa Kelas XI IPA di SMA Negeri 1 Rembang Kabupaten Purbalingga, Skripsi- Institut Agama Islam Negeri Purwokerto, 2017. 
Muhammadiyah 5 Karanganyar, Jaten, Karanganyar)". ${ }^{6}$ Dalam penelitian ini menjelaskan bahwa adapun strategi dalam meningkatkan kedisiplinan siswa sebagai berikut: memberikan reward, memberikan sanksi atau hukuman (punishment), pembuatan jadwal tabel Shalat, memberi contoh berpenampilan yang rapi, memeriksa siswa kelengkapan atribut siswa, mengatasi siswa di dalam kelas dengan membuat kelompok belajar.

\section{Kerangka Teori}

\section{Peran Guru Pendidikan Agama}

Islam. Guru disebut sebagai seorang pendidik. Pendidik adalah bapak rohani (spiritual father) bagi peserta didik, yang memberikan santapan jiwa dengan ilmu, pembinaan, akhlak mulia, dan meluruskan perilakunya yang buruk. ${ }^{7}$ Oleh karenanya, pendidik mempunya kedudukan tinggi dalam Islam. Menurut Roestiyah NK fungsi dan peran pendidik (yang diidentikkan sebagai guru) menjadi tiga bagian yaitu ${ }^{8}$ pertama, sebagai pengajar (instruksional), yang bertugas merencanakan program pengajaran dan melaksanakan program yang telah disusun serta mengakhiri dengan

\footnotetext{
${ }^{6}$ Himawan Puput Raharjo, Strategi Guru Pendidikan Agama Islam dalam Meningkatkan Kedisiplinan Siswa Kelas XI IPS 1 (Studi Kasus di SMA Muhammadiyah 5 Karanganyar, Jaten, Karanganyar), Skripsi-Institut Agama Islam Negeri Surakarta, 2017.

${ }^{7}$ Abdul Mujib, Ilmu Pendidikan Agama Islam, (Jakarta: Kencana, 2006), hal. 88.
}

pelaksanaan penilaian setelah program dilakukan. Kedua, sebagai pendidik (educator), yang meng-arahkan peserta didik pada tingkat kedewasaan dan berkepribadian kamil seiring dengan tujuan Allah swt menciptakannya. Ketiga, sebagai pemimpin (managerial), yang memimpin, mengendalikan kepada diri sendiri, peserta didik dan masyarakat yang terkait, terhadap berbagai masalah yang menyangkut upaya pengarahan, pengawasan, pengorganisasian, pengontrolan, dan partisipasi atas program pendidikan yang dilakukan. Nizar mengatakan bahwa rangkaian tugas guru dalam mendidik, yaitu rangkaian mengajar, memberikan dorongan, memuji, memberikan hukuman dan contoh, serta membiasakan. ${ }^{9}$ Barnadib menambah-kan bahwa tugas guru terkait dengan perintah, larangan, menasihati, hadiah, pemberian kesempatan, dan menutup kesempatan. ${ }^{10}$ Jadi, peran guru bukanlah hanya mengajar atau menyampaikan materi saja, namun peran guru juga sebagai pendidik, motivator, dan suri teladan bagi peserta didik.

Pengertian Kedisiplinan. Kedisiplinan berasal dari kata disiplin yang awalan ke-

\footnotetext{
${ }^{8}$ Roestiyah NK, Masalah-masalah Ilmu Keguruan, (Jakarta: Bina Aksara, 1982), hal. 86.

${ }^{9}$ Samsul Nizar, Filsafat Pendidikan Islam (Pendekatan Teoritis dan Praktis), (Jakarta: Ciputat Press, 1993), hal. 44.

${ }^{10}$ Sutari Imam Barnadib, Pengantar Ilmu Pendidikan Sistematis, (Yogyakarta: Andi Ofset, 1993), hal. 40.
} 
dan akhiran -an, menurut Kamus Besar Bahasa Indonesia (KBBI) disiplin mempunyai arti ketaatan dan kepatuhan pada aturan, tata tertib, dan lain sebagainya. ${ }^{11}$ Disiplin merupakan suatu sikap atau perilaku yang sangat diharapkan oleh seorang pendidik (guru) dalam proses pembelajaran baik di dalam maupun di luar kelas dapat berjalan dengan baik dan lancar. Sedangkan menurut salah satu dari para ahli yakni menurut Muhammad Idris Jauhari disiplin adalah seperangkat aturan, tata tertib, tatanan atau hukum yang mengikat seseorang untuk dipatuhi dan dijalankan sebagaimana mestinya. ${ }^{12}$ Jadi, disiplin adalah seperangkat aturan, tata tertib yang telah disusun sedemikian rupa untuk dipatuhi dan dijalankan dengan baik.

Fadhilah Shalat Berjamaah. Salat adalah kewajiban bersifat individual ( fardl 'ain) yang penyelenggaraannya disunatkan berjamaah (khususnya untuk shalat wajib). Hal ini keutamaannya terdapat dalam hadis yang artinya," shalat berjamaah lebih utama dengan nilai dua puluh derajat daripada shalat sendiri". Hadits tersebut menerangkan bahwa tidak ada fadhilah yang lebih besar dari shalat berjamaah. Jadi, dengan kita melaksanakan shalat berjamaah akan mendapat pahala yang lebih besar.

\footnotetext{
${ }^{11}$ Tim Penyusun Kamus Pusat Pembinaan dan Pengembangan, Kamus Besar Bahasa Indonesia, (Jakarta: Balai Pustaka, 1997), hal. 747.
}

\section{METODE PENELITIAN}

Penelitian ini menggunakan pendekatan kualitatif, penelitian kualitatif adalah penelitian yang menghasilkan data deskriptif berupa kata-kata tertulis atau lisan dari orang-orang dan perilaku yang dapat diamati. Pendekatan ini diarahkan pada latar dan individu tersebut secara holistik (utuh). Adapun sumber data yang digunakan untuk penelitian ini adalah terdiri dari 2 data yaitu data primer dan data sekunder. Metode pengumpulan data pada penelitian ini berupa observasi, wawancara, dan dokumentasi. Teknik analisis data ada tiga langkah yakni reduksi data, penyajian data, dan penarikan kesimpulan. Adapun uji keabsahan data dalam penelitian ini menggunakan teknik triangulasi.

\section{HASIL PENELITIAN DAN PEMBA- HASAN}

Peran Guru PAI Dalam Mendi-
siplinkan Shalat Berjamaah Peserta
Didik di SMK Muhammadiyah 3 Gresik
Guru sangat berperan penting bagi
perkembangan peserta didik baik dari fisik
maupun psikis. Psikis ini berhubungan
dengan jiwa spiritual atau kerohaniannya.
Hal tersebut dapat muncul pada setiap
peserta didik dengan kegiatan-kegiatan
keagamaan. Kegiatan keagamaan ini

${ }^{12}$ M. Idris Jauhari, Disiplin dan Hidup Berdisiplin, hal. 1. 
misalnya shalat berjamaah ketika dhuha, dhuhur, dan ashar. Kegiatan tersebut bisa berjalan disiplin, pastinya diperlukan peran semua guru di sekolah. Namun, guru PAI yang memiliki tanggung jawab penuh. Sebagaimana diungkapkan oleh Bapak Didik Purnomo yakni: "untuk mendisiplinkan peserta didik ini memang yang diberikan tanggung jawab penuh adalah guru PAI, tetapi guru lain pun juga tetap berperan. Misalnya, pada waktu shalat berjamaah semua guru wajib untuk pergi ke masjid, dan ada guru yang bertugas untuk ngobraki peserta didik, serta guru yang mendapat jam pelajaran terakhir berhak mengingatkan kepada peserta didik untuk bergegas ke masjid." 13

Hal ini menunjukkan bahwa semua guru berperan dalam mendisiplinkan shalat berjamaah peserta didik. Sebagaimana menurut Roestiyah NK dalam bukunya masalah-masalah ilmu keguruan bahwa tidak hanya sebagai pengajar melainkan sebagai pendidik dan pemimpin. ${ }^{14}$ Maksudnya selain guru itu sebagai pengajar yaitu memberikan materi saat pembelajaran, namun guru juga sebagai pendidik dan pemimpin yaitu misalnya mendisiplinkan shalat berjamaah peserta didik.
Ibu Yussi menambahkan mengenai peran guru PAI dalam mendisiplinkan shalat berjamaah, beliau mengungkapkan bahwa: "peran guru PAI dalam mendisiplinkan shalat berjamaah yakni sebagai contoh/ teladan misalnya berangkat ke masjid terlebih dahulu, memberikan nasihat kepada peserta didik selesai shalat, kemudian memberikan hukuman bagi peserta didik yang tidak disiplin"15

Adapun hasil observasi menyatakan bahwa guru PAI sangat berperan bagi kedisiplinan shalat berjamaah peserta didik. Terbukti ketika tidak ada guru PAI yang mengobrak peserta didik ke masjid, kemudian tidak ada guru yang berangkat lebih dulu ke masjid. Maka yang terjadi, beberapa peserta didik malah tidak segera bergegas ke masjid melainkan memilih duduk-duduk di kantin, sehingga shalatnya telat dan tidak disiplin.

Bapak Didik Purnomo mengungkapkan mengenai hukuman bagi yang tidak disiplin, beliau ungkapkan sebagai berikut: "ketika peserta didik tidak tertib shalatnya maka, yang dilakukan adalah menyuruh mengulang lagi shalatnya, kemudian bagi yang tidak shalat berjamaah ia akan shalat di lapangan.",16

\footnotetext{
${ }^{15}$ Wawancara dengan Yussi Fadlilatun N, S.Pd (selaku Guru PAI) pada 9 April 2019.

${ }^{16}$ Wawancara dengan H. Didik Purnomo, Lc, M.Ag (selaku Guru PAI) pada 11 April 2019.
} 
Bapak Ammar membenarkan pernyataan Bapak Didik Purnomo, beliau mengungkapkan bahwa: "peserta didik yang tidak shalat berjamaah kami suruh untuk shalat di lapangan dan bagi yang tidak disiplin dalam shalat kami suruh untuk mengulang shalatnya. Hal ini kami lakukan agar peserta didik tidak mengulang kesalahannya lagi". ${ }^{17}$

Hasil observasi menyatakan bahwa apabila ada peserta didik yang kurang disiplin maka guru PAI berperan yaitu memberikan hukuman bagi peserta didik yang bersangkutan. Bentuk hukumannya disajikan dalam bentuk gambar terlampir.

Berdasarkan hasil wawancara dan observasi mengenai adanya pemberian hukuman yang dilakukan guru PAI di atas merupakan salah satu cara mendidik peserta didik. Hal ini selaras dengan ungkapan Nizar dalam bukunya filsafat pendidikan Islam bahwa rangkaian tugas guru dalam mendidik, yaitu rangkaian mengajar, memberikan dorongan, memuji, memberikan hukuman dan contoh, serta membiasakan. ${ }^{18}$

Peran guru PAI dalam mendisiplinkan shalat berjamaah peserta didik tidak hanya memberi hukuman, melainkan memberikan nasihat juga. Ibu Yussi mengatakan bahwa "upaya mendisiplinkan peserta didik yaitu memberikan nasihat."19

Hal tersebut dibenarkan oleh Bapak Didik Purnomo, beliau mengungkapkan sebagai berikut: "Memang benar sering kali setelah melaksanakan shalat berjamaah salah satu guru PAI kadang saya, bu Yussi, pak Ammar memberikan mauidhatul hasanah (nasihat yang baik) dan hal ini dilakukan agar peserta didik ini imannya terus bertambah sehingga menjadikan mereka pribadi yang lebih baik." 20

Hasil observasi menyatakan bahwa memang setiap setelah shalat berjamaah guru PAI memberikan nasihat dan pengarahan bagi peserta didik. Dan hal tersebut tidak hanya dilakukan oleh guru PAI, terkadang kalau guru PAI berhalangan hadir maka ada guru lain yang menggantikan tugasnya. Hal tersebut peneliti mengetahuinya ketika magang di SMK Muhammadiyah 3 Gresik.

Peran guru PAI di SMK Muhammadiyah 3 Gresik selain memberikan contoh dan hukuman yaitu memberikan nasihat, hal ini selaras dengan ungkapan Barnadib dalam bukunya pengantar ilmu pendidikan sistematis bahwa salah satu tugas seorang guru

\footnotetext{
${ }^{19}$ Wawancara dengan Yussi Fadlilatun N, S.Pd (selaku Guru PAI) pada 9 April 2019.

${ }^{20}$ Wawancara dengan H. Didik Purnomo, Lc, M.Ag (selaku Guru PAI) pada 11 April 2019.
} 
adalah memberikan sebuah nasihat kepada peserta didik. $^{21}$

Dari analisis di atas, dapat peneliti simpulkan bahwa peran guru PAI dalam mendisiplinkan shalat berjamaah peserta didik adalah pertama, sebagai teladan artinya dapat dijadikan panutan dan dapat memberikan contoh yang baik terhadap peserta didik. Seperti paradigma Jawa yang mengatakan guru itu "digugu dan ditiru". Berarti guru PAI khususnya harus dapat menjadi panutan dengan memberikan contoh misalnya pergi ke masjid lebih dulu daripada peserta didik. Dengan hal tersebut dilakukan, maka akan membuat peserta didik lebih semangat bergegas ke masjid melakukan shalat berjamaah. Kedua, memberikan nasihat yang baik (mauidhotul hasanah). Itu merupakan tugas seorang guru. Seperti diungkapkan Barnadib bahwa tugas guru adalah memberikan nasihat. ${ }^{22}$ Dalam hal ini guru PAI memberikan nasihat kepada peserta didik setelah shalat guna menambah spiritual peserta didik. Setelah guru PAI memberikan pengertian, nasihat dan lain-lain esoknya mereka tidak mengulangi kesalahannya lagi, shalat berjalan disiplin tanpa diobrak. Ketiga, memberikan hukuman. Hukuman ini gunanya memberikan efek jera kepada peserta didik agar lebih

\footnotetext{
${ }^{21}$ Sutari Imam Barnadib, Pengantar Ilmu Pendidikan Sistematis, (Yogyakarta: Andi Ofset, 1993), hal. 40.
}

disiplin. Hukuman tersebut berupa shalat di lapangan dan mengulang shalatnya. Dengan hukuman tersebut peserta didik akan merasa malu karena dilihat semua teman-temannya, sehingga dengan rasa malu tersebut kesalahan yang dilakukan tidak terulang.

\section{Faktor Pendukung dan Penghambat} Dalam Mendisiplinkan Shalat Berjamaah

Dalam mendisiplinkan shalat berjamaah peserta didik pastinya ada faktor pendukung dan penghambat. Faktor pendukung tersebut adalah beberapa hal yang dapat memudahkan guru dalam mendisiplinkan. Kemudian faktor penghambat adalah hal-hal yang dapat membuat guru merasa kesulitan dalam mendisiplinkan.

Hasil wawancara dengan Bapak Didik Purnomo mengenai faktor pendukung dalam mendisiplinkan shalat berjamaah peserta didik yakni: "faktor pendukung atau memudahkan kami dalam mendisiplinkan adalah adanya kerja sama dengan semua pihak guru dan peran guru PAI."23

Ungkapan tersebut dibenarkan oleh Bapak Kepala Sekolah yakni Bapak Su'aib sebagai berikut: "ketika shalat berjamaah menjadi tugas bersama antara guru PAI dan

\footnotetext{
${ }^{22}$ Sutari Imam Barnadib, Pengantar Ilmu Pendidikan Sistematis, (Yogyakarta: Andi Ofset, 1993), hal. 40.

${ }^{23}$ Wawancara dengan H. Didik Purnomo, Lc, M.Ag (selaku Guru PAI) pada 11 April 2019.
} 
guru yang lain. Misalnya, apabila tidak ada halangan maka semua guru dan saya wajib ke masjid. Sebab itu dapat memudah-kan dalam mendisiplinkan shalat berjamaah peserta didik dan memberikan stimulus pada peserta didik." 24

Hal tersebut juga diungkapkan oleh Ibu Yussi, beliau menyatakan bahwa: "kami sebagai guru PAI membagi tugas pada guru yang lain bahwa ketika waktunya shalat berjamaah, guru yang berada di kelas pada jam terakhir bertugas untuk mengingatkan peserta didik agar bergegas ke masjid, sedangkan guru yang ada di kantor ngobrak peserta didiknya dan guru PAI ke masjid terlebih dahulu serta semua guru diharuskan shalat berjamaah di masjid." 25

Alasan mengenai semua guru harus berperan telah diungkapkan oleh Ibu Yussi yakni: "ketika semua guru berperan dalam mendisiplinkan pada waktu shalat berjamaah, peserta didik itu mempunyai rasa greget untuk ke masjid dan lebih disiplin waktu khususnya dalam shalat berjamaah.",26

Hasil observasi menyatakan bahwa ketika adanya kerja sama guru PAI dengan guru yang lain, maka peserta didik itu lebih semangat ke masjid dan lebih mudah dikondisikan.

\footnotetext{
${ }^{24}$ Wawancara dengan Drs. Su'aib, MM pada 11 April 2019.

${ }^{25}$ Wawancara dengan Yussi Fadlilatun N, S.Pd (selaku Guru PAI) pada 9 April 2019.
}

Maka dapat disimpulkan bahwa faktor pendukung dalam mendisiplinkan shalat berjamaah peserta didik ada 2 hal yaitu, pertama adanya kerja sama dengan semua pihak guru. Maksudnya adalah dalam mendisiplinkan perlu kerja sama dengan semua pihak guru, misalnya ketika waktu shalat guru yang berada di jam pelajaran terakhir mengingatkan kepada peserta didik untuk segera bergegas ke masjid, membantu guru PAI ngobrak peserta didik, dan ikut ke masjid juga. Hal ini bertujuan untuk menambah semangat peserta didik pergi ke masjid untuk melaksanakan shalat berjamaah dan membuat peserta didik itu merasa ada yang mendampingi. Kedua, peran guru PAI yang berjalan dengan baik. Dapat peneliti bandingkan ketika tidak ada peran guru PAI dalam pendisiplinan shalat berjamaah peserta didik dan adanya peran guru PAI. Ketika tidak hadirnya sosok guru PAI, peserta didik banyak yang telat ke masjid dan sulit diarahkan. Hal itu bisa terjadi disebabkan tidak ada guru yang berangkat lebih dulu ke masjid dan tidak akan ada hukuman yang diberikan ke peserta didik apabila melakukan hal tersebut, karena yang biasanya memberikan hukuman tidak hadir. Kemudian, apabila hadirnya sosok guru PAI, peserta didik segera bergegas ke

\footnotetext{
${ }^{26}$ Wawancara dengan Yussi Fadlilatun N, S.Pd (selaku Guru PAI) pada 9 April 2019.
} 
masjid karena ada salah satu guru PAI yang sudah berangkat lebih dulu dan akan ada hukuman bagi peserta didik yang telat.

Itu merupakan faktor pendukungnya, berikut ada faktor penghambat dalam mendisiplinkan shalat berjamaah peserta didik. Hasil wawancara dengan Ibu Yussi mengenai faktor penghambat dalam mendisiplinkan shalat berjamaah peserta didik beliau mengungkapkan bahwa "peserta didik sulit didisiplinkan, ada beberapa faktor penghambat yakni lokasi masjid dan waktu."27

Hal itu juga diungkapkan oleh bapak Didik Purnomo, beliau mengungkapkan bahwa: "alasan peserta didik malas ke masjid dan shalat berjamaah yakni lokasi masjid yang cukup jauh dengan sekolah dan mereka harus jalan kaki. Kemudian, pada waktu shalat dhuhur mereka harus ke masjid dengan hawa yang panas dan pada jam segitu peserta didik mulai lelah-lelahnya untuk gerak." 28

Pernyataan tersebut dibenarkan oleh peserta didik yang bernama Andika kelas 10 TITL 2 bahwa: "saya sebagai peserta didik itu kadang malas ke masjid, sebab yang membuat kita tidak disiplin yaitu jarak

\footnotetext{
${ }^{27}$ Wawancara dengan Yussi Fadlilatun N, S.Pd (selaku Guru PAI) pada 9 April 2019.

${ }^{28}$ Wawancara dengan H. Didik Purnomo, Lc, M.Ag (selaku Guru PAI) pada 11 April 2019.
}

sekolah ke masjid itu jauh dan kalau waktu shalat dhuhur itu panas." 29

Berarti dapat disimpulkan bahwa ada 2 hal yang menjadi faktor penghambat dalam mendisiplinkan shalat berjamaah peserta didik adalah pertama, lokasi masjid. Lokasi masjid tersebut berada di dalam perkampungan. Dan jarak antara masjid dan sekolah cukup jauh. Meskipun masih bisa ditempuh dengan jalan kaki. Kalau ketika shalat dhuha peserta didik masih semangat ke masjid dan didisiplinkannya pun mudah karena masih pagi. Tetapi ketika sudah siang mau Shalat dhuha mereka sudah bermalasan ke masjid, kadang ada yang masih duduk-duduk di kantin. Kedua, waktu. Waktu ini maksudnya ketika masih pagi waktu Shalat dhuha peserta didik masih semangat ke masjid. Namun ketika sudah siang waktu Shalat dhuhur mereka mulai banyak yang tidur di kelasnya kemudian bermalasan ke masjid, sehingga berakibat ke masjidnya telat dan tidak shalat berjamaah ke masjid.

\section{PENUTUP}

\section{Kesimpulan}

Berdasarkan uraian hasil penelitian yang telah dikembangkan di bab sebelumnya, maka dapat disimpulkan bahwa peran guru Pendidikan Agama Islam dalam men-

\footnotetext{
${ }^{29}$ Wawancara dengan Andika (peserta didik kelas 10 TITL 2) pada 11 April 2019.
} 
disiplinkan shalat berjamaah peserta didik di SMK Muhammadiyah 3 Gresik antara lain:

1. Memberikan teladan/contoh bagi peserta didik khususnya dalam shalat berjamaah.

2. Memberikan nasihat yang baik (mauidhatul hasanah) dalam hal keagaamaan.

3. Memberikan hukuman bagi peserta didik yang tidak patuh.

Dari ketiga peran tersebut, tujuannya agar peserta didik menjadi pribadi yang lebih baik khususnya dalam kedisiplinan pada kegiatan keagamaan. Dan hal tersebut tidak hanya dimiliki guru PAI saja, namun semua guru yang ada di SMK Muhammadiyah 3 Gresik.

Dalam mendisiplinkan shalat berjamaah peserta didik di SMK Muhammadiyah 3 Gresik ada faktor pendukung dan faktor penghambat, antara lain sebagai berikut:

Faktor Pendukung:

1. Kerja sama yang baik antara guru PAI dengan guru yang lain

2. Peran guru PAI yang berjalan dengan baik

Faktor Penghambat:

1. Lokasi (letak masjid dan sekolah cukup jauh)

2. Waktu (kalau siang hari waktu shalat dhuhur itu panas).

\section{Saran}

Ada beberapa saran yang penulis sampaikan kepada pihak yang terkait dengan hal ini yaitu dengan sudah berjalannya pelaksanaan shalat berjamaah di SMK Muhammadiyah 3 Gresik harus lebih baik, misalnya dengan pengadaan buku ibadah untuk peserta didik dan dipupuk terus kerja sama yang baik antara kepala sekolah, guru, peserta didik, dan orang tua.

\section{DAFTAR PUSTAKA}

Barnadib, Sutari Imam. 1993. Pengantar Ilmu Pendidikan Sistematis,. Yogyakarta: Andi Ofset.

Huda, Nurul. 2015. Peran Guru Terhadap Keaktifan Siswa Melaksanakan Shalat, Skripsi-- Institut agama Islam Negeri Salatiga.

Jauhari, Muhammad Idris. 2011. Disiplin dan Hidup Disiplin. Sumenep: Mutiara Press Al Amien Prenduan.

Nizar, Samsul. 1993. Filsafat Pendidikan Islam (Pendekatan Teoritis dan Praktis). Jakarta: Ciputat Press.

NK, Roestiyah. 1982. Masalah-masalah Ilmu Keguruan. Jakarta: Bina Aksara.

Raharjo, Himawan Puput. 2017. Strategi Guru Pendidikan Agama Islam dalam Meningkatkan Kedisiplinan Siswa Kelas XI IPS 1 (Studi Kasus di SMA Muhammadiyah 5 Karanganyar, Jaten, Karanganyar), Skripsi-Institut Agama Islam Negeri Surakarta, 2017. 
Rusman. 2017. Belajar dan Pembelajaran. Jakarta: Kencana.

Sangadah, Ulfa Nurul. 2017. Peran Guru Pendidikan Agama Islam dan Orang Tua dalam Membentuk Kedisiplinan Ibadah Siswa Kelas XI IPA di SMA Negeri 1 Rembang Kabupaten Purbalingga, Skripsi-- Institut Agama Islam Negeri Purwokerto.

Sudewo, Erie. 2011. Character Building Menuju Indonesia Lebih Baik. Jakarta: Republika.

Tim Penyusun Kamus Pusat Pembinaan dan Pengembangan. 1997. Kamus Besar Bahasa Indonesia,. Jakarta: Balai Pustaka.
Wawancara dengan H. Didik Purnomo, Lc, M.Ag (selaku Guru PAI) pada 11 April 2019.

Wawancara dengan Yussi Fadlilatun N, S.Pd (selaku Guru PAI) pada 9 April 2019.

Wawancara dengan Fakhruddin Muammar, S.Pd (selaku Guru PAI) pada 11 April 2019.

Wawancara dengan Drs. Su'aib, MM pada 11 April 2019.

Wawancara dengan Andika (peserta didik kelas 10 TITL 2) pada 11 April 2019. 
Jurnal TAMADDUN - FAI UMG. Vol. XX. No.2 / Juli 2019 